\title{
吉野川河口における河床変動要因の解析 ANALYSIS OF FACTORS WHICH CONTRIBUTE TO RIVER-BED VARIATION AT YOSHINO RIVER MOUTH
}

\author{
宇野宏司 $1 \cdot$ 中野晋 $2 \cdot$ 辻本剛三 $3 \cdot$ 柿木哲哉 4 \\ Kohji UNO, Susumu NAKANO, Gozo TSUJIMOTO and Tetsuya KAKINOKI \\ 1正会員 博 (工) 神戶市立工業高専助手 都市工学科 (广 651- 2194 神戶市西区学園東町8 3) \\ 2正会員 博 (工) 徳島大学助教授 工学部建設工学科 (广 770-8506 徳島市南三島町2-1) \\ 3フェロー会員 工博 神戶市立工業高専教授 都市工学科 (广 651- 2194 神戶市西区学園東町8 3) \\ 4 正会員 博 (工) 神戶市立工業高専助教授 都市工学科 (广 651- 2194 神戶市西区学園東町8 3)
}

\begin{abstract}
To clarify the contributing factors for river-bed variations, numerical simulation and statistical analysis were conducted. The study site is the Yoshino river mouth, Shikoku island, Japan. At first, under the unsteady flow condition, 1-D numerical simulations on river-bed variations were carried out and the reproducible results were obtained. Secondary, the empirical eigenfunction was applied to the simulation results and survey data, respectively. Finally, contributing factors for river-bed variations were estimated by principal component analysis. Main results are as follows; 1) The results of numerical simulation agree well with the topographic data, except for some local scouring spots and $0-2 \mathrm{~km}$ section. 2) The first principal component which is obtained by EOF analysis reflects the effect of cross-shore sediment transport. 3) The river-bed variation at the Yoshino river-mouth can be described by using top three principal components.
\end{abstract}

Key Words : cross-shore sediment transport, empirical eigenfunction, Yoshino river

\section{1 .はじめに}

河川の総合的な維持管理にあたっては，大規模出 水等のcat ast r ophi cな状況を想定するだけでなく， 中長期的な視点に基づいて対象河川の变遷を把握し， 適当な対策を講じていく必要がある．炎のためには， これまでに蓄積された測量データ等を解析し河床変 動に寄与する因子を明らかにすることが重要である が，具体的な解析方法や予測手法の確立には多くの 課題を残している.

特に河川と海岸が接続する河口域は, 河川改修や 流域開発等の人為的なインパクトと, 洪水, 潮汐, 波浪等の自然現象によるインパクトが複雑に絡み合 うため, 河口地形に寄与する因子を抽出することが 困難な状況にある .

加藤・吉松1)，中野・岡部2) は，測量データをも とに経験的固有関数法を用いて, 地形変動の因子分 析を行い, 弚の有用性を確認している.しかし，将 来施策を検討するにあたっては，数値シミュレー ション結果に対する同手法の有効性を確認しておく ことも必要である.

本研究で対象とする吉野川河口域では, 現在, 東
環状大橋の建設工事が進行しているほか , 第十堰改 筑問題や, 四国横断道路橋の建設, 沖洲流通港湾2 期工事か計画されている．また，人為的なインパク 卜に加え, 近年では, 地球温暖化の影響による海水 準上昇が河口域の生態系等に及ぼす影響も懸念され 始めている.德島県近海においても，年間 $5.5 \mathrm{~mm}$ 速度で海水準面が上昇しているとの報告3)がある . 河口域の環境への影響に対する地域住民の関心は非 常に高いものとなっており，工学的・科学的立場か らの説明責任が求められている.

このような社会的背景を踏まえて, 本研究では, 河口域における中長期的なトレンドを評価する一手 法として, 比較的計算負荷が小さい一次元河床変動 解析結果を対象に統計的解析手法を適用し，河口域 の変動に寄与する因子の抽出と光の影響度を定量的 に把握することを試みた .

\section{2. 一次元河床変動計算モデル}

\section{(1) 計算モデルの概要 ${ }^{4), 5)}$}

本モデルでは陰形式差分法で不定流計算を行い， 各地点の時々刻々の水位を求め，これをもとに摩擦 

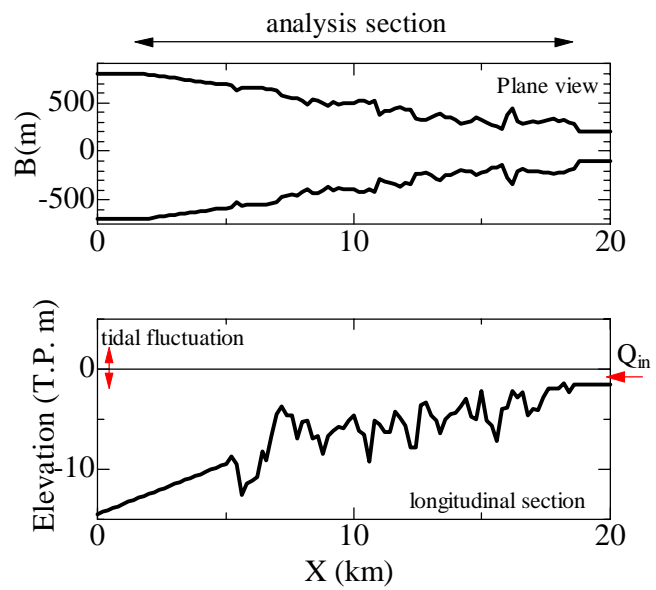

図- 1 計算地形

速度を評価し，河床変動量を計算する．

陰形式差分法による不定流計算では， $\Delta x ， \Delta t$ の大小に関わらず計算が安定するという特長をもつ ため，中長期的な計算をする場合に有利である .

不定流計算における流れの基本方程式は，式 (1), (2)であらわされる .

$$
\begin{aligned}
& \frac{\partial A}{\partial t}+\frac{\partial Q}{\partial x}=0 \\
& \frac{1}{g A} \frac{\partial Q}{\partial t}+\frac{2 Q}{g A^{2}} \frac{\partial Q}{\partial x}-\frac{Q^{2}}{g A^{3}} \frac{\partial A}{\partial x}+\frac{\partial H}{\partial x}+\frac{Q|Q|}{k^{2}}=0
\end{aligned}
$$

ここに, $A$ : 通水断面積, $t:$ : 時間, $Q:$ 流量,

$x$ : 下流向きを正とする距離, $k^{2}$ : 通水能である

河床変動計算では, 河床材料及び流砂は混合砂磁 を対象とした . また流砂形態は掃流砂及び浮遊砂を 対象とした . 掃流砂量の算出には粒径別の芦田・道 上の式を用いた . 一方, 浮遊砂の河床からの浮上量 については , 板倉・岸の式を用いた .

粒径別流砂の連続式は，交換層における粒径別の 流砂の交換, 河床の変動及び河床変動に伴って新た に交換層に加わる粒径分布を考慮し，次式で表され る。

$$
\begin{aligned}
\delta \frac{\partial p_{i}}{\partial t} & +p_{i}^{*} \frac{\partial \eta}{\partial t} \\
& +\frac{1}{1-\lambda}\left[\frac{1}{B} \frac{\partial\left(q_{B i} B\right)}{\partial x}+q_{s u i}-w_{f i} c_{b i}\right]=0
\end{aligned}
$$

ここに, $p_{i}$ : 粒度構成比， $\delta$ : 交換層厚さ， $\lambda$ : 河床材料の空隙率, $q_{s u i}$ : 粒径別浮遊砂の単位面積 当たりの河床からの浮上量, $q_{B i}$ : 粒径別掃流砂量, $w_{f i}:$ 粒径別浮遊砂の沈降速度 (Rubey式より算 出）, $c_{b i}$ : 河床付近の粒径別浮遊砂濃度である. なお，式(3)の $p_{i}^{*}$ に関しては，河床上昇の場合には 流砂中における粒度構成 $p_{i}$ を, 河床低下の場合に は初期河床での粒度構成 $p_{i 0}$ を与えることとした 。

また，全流砂の連続式は全ての粒径の流砂の交換 を考慮し，次式で表される．

\begin{tabular}{|c|c|c|c|c|c|}
\hline \multirow[b]{2}{*}{$\begin{array}{c}\text { 計算 } \\
\text { ケース }\end{array}$} & \multirow[b]{2}{*}{$\begin{array}{l}\text { 上流端 } \\
\text { 流量 }\end{array}$} & \multirow[b]{2}{*}{$\begin{array}{l}\text { 下流端 } \\
\text { 水位 }\end{array}$} & \multirow{2}{*}{$\begin{array}{l}\text { 砂 } \\
\text { 利 } \\
\text { 採 } \\
\text { 取 }\end{array}$} & \multicolumn{2}{|c|}{ 流砂形態 } \\
\hline & & & & 掃流砂 & 浮遊砂 \\
\hline case01 & 0 & 0 & 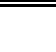 & 0 & 0 \\
\hline case02 & 0 & 0 & O & 0 & - \\
\hline case03 & $\bigcirc$ & 0 & $x$ & 0 & $\bigcirc$ \\
\hline case04 & 0 & $x$ & $x$ & 0 & 0 \\
\hline case05 & $x$ & O & $x$ & O & O \\
\hline
\end{tabular}

$$
\frac{\partial \eta}{\partial t}+\frac{1}{1-\lambda}\left[\frac{1}{B} \frac{\partial \sum_{i}\left(q_{B i} B\right)}{\partial x}+\sum_{i}\left(q_{s u i}-w_{f i} c_{b i}\right)\right]=0
$$

表- 1 計算条件

ここで， $\Sigma_{i}$ は粒径別の量を合計した量である．

黑木ら によよば，安定した河床変動計算を行う ためには，時間及び空間方向の計算刻みが次式の条 件を満たす必要があるとされている . 本モデルの不 定流計算では陰形式をとるため $\Delta t$ の制約を受けな い.したがって，式 (5) が本モデルの $\Delta t$ の制約条 件となる 。

$$
\frac{\Delta t}{\Delta x} \leq \min \left[\left(\frac{d x}{d t}\right)_{p i}^{-1}\right]
$$

ここに，

$$
\left(\frac{d x}{d t}\right)_{p i}=\frac{-1}{B \delta(1-\lambda)}\left[\frac{\partial\left(q_{B i} B\right) / \partial x}{\partial p_{i} / \partial x}+Q \frac{\partial c_{i} / \partial x}{\partial h / \partial x}\right]
$$

（2）モデルによる中長期的な河床変動の再現性

本モデルによる中長期的な河床変動の再現性を確 認するため, 吉野川河口での河床変動の再現計算を 行った。初期断面形状 (川幅, 河床高) は, 1966年 の横断測量データより図-1のとおり設定した . 計算 条件は, 表-1に示す5ケースとし, 上流端流量，下 流端水位, 砂利採取の有無, 流砂形態力地形変動に 与える影響を把握することを試みた。計算期間はい ずれも1966〜2002年の37年間である. 中野・岡部2) によれば，吉野川河口域では近年，澪筋を中心に顕 著な河床位の上昇が見られると報告されている．光 こで, 本研究では河床位について各断面の澪筋に相 当すると考えられる最深河床位を用いることとした．

河床材料の初期粒度分布は, $10,50,90 \%$ 粒径を 与え，対数正規分布になるように内挿して分布を与 えた.ここで, $50 \%$ 粒径は, 各断面の平均水深から 求まる移動限界粒径と同等になるよう設定した . ま た，10\%，90\%粒径は光れ光れ50\%粒径の1/10，2 倍とした。

不定流計算では, 境界条件として上流端流量と下 流端水位を設定する必要がある．乥こで上流端流量

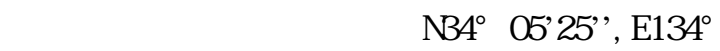

20’52”）の日流量を与えた．また，下流端水位は， 吉野川河口に最も近い小松島港での実測潮位を与え， 欠測の場合は推算潮位で補間した .

浮遊砂は上下流端で動的平衡状態であるとして， 次式に示す平衡浮遊砂濃度を与えた。 

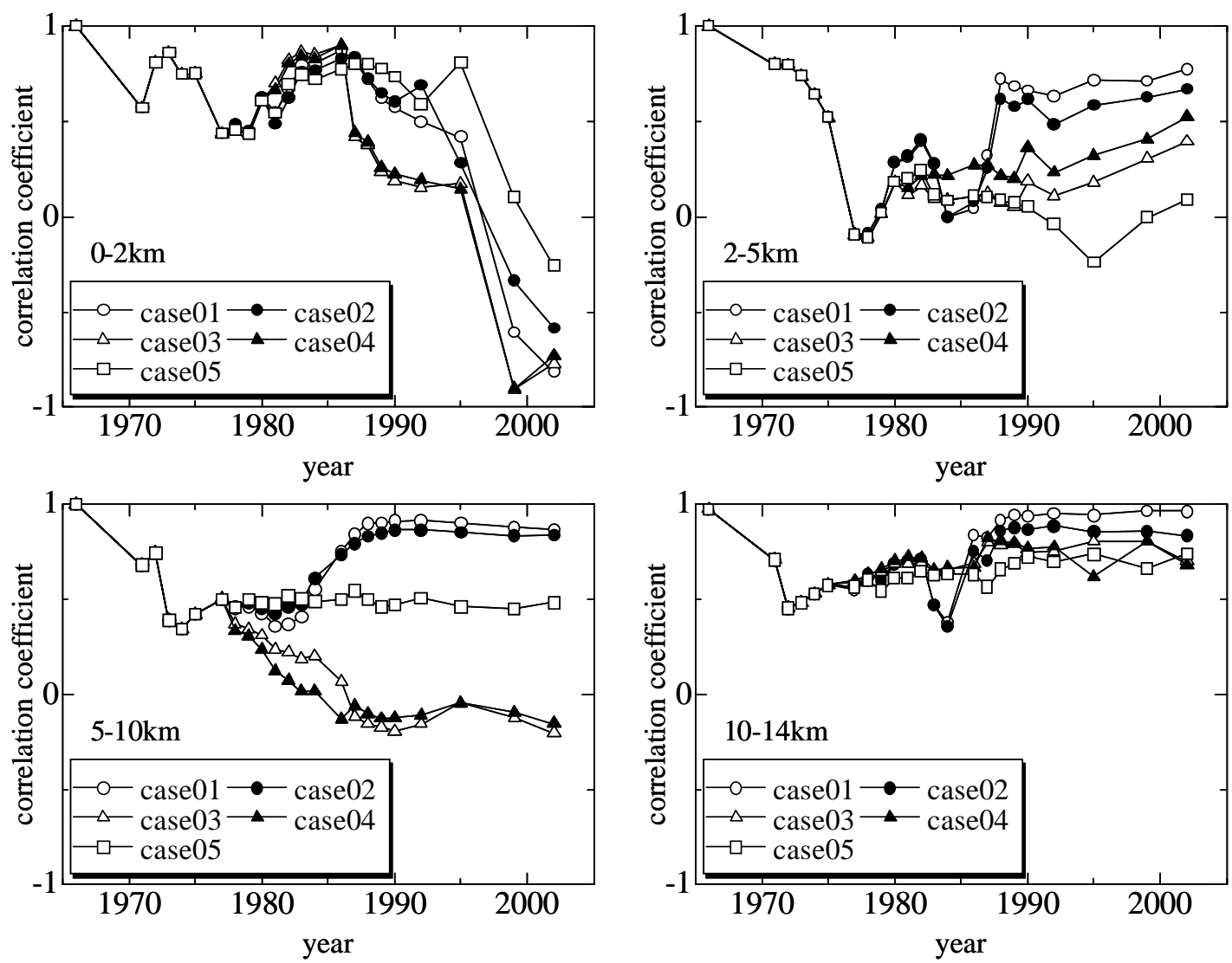

图-2 区間別の相関係数

$$
\left\langle c_{i}\right\rangle=\frac{q_{\text {sui }}}{w_{f 1} \beta}(1-\exp (-\beta))
$$

ここに, $\beta=w_{f l} h / \varepsilon(\varepsilon$ は水深平均の拡散係数 でカルマン定数 $\kappa$ を用いて， $\left.\varepsilon=u_{*} h / 6\right)$ と表され る。

図-2は区間ごとに各計算ケースの計算結果と実測 データとの相関係数を時系列でプロットしたもので ある．0-2km区間では，いずれの計算ケースも1990 年以降に相関が著しく低くなっている．しかし， case01とcase02については，0-2kn区間を除いては 全期間にわたり相関係数0.6以上を保っており，実 現象をかなり簡略化した一次元モデルとしては比較 的良好な再現結果が得られている.

case03とcase04については，5-10kn区間において も相関か著しく低くなっている．各計算ケースは case01の計算条件から, 砂利採取, 上流からの河川 水供給といった因子を除いて計算したものであり， 今回の計算結果からは, これらの因子か地形変動に 強く影響を与えていることがわかる.一方, case05 は潮位変動が河床変動に及ぼす影響を調べたもので あるが, 相関係数の低下具合からみても, 砂利採取 や上流からの河川水供給に比べて光の影響は小さい と考えられる .

図-3は今回の計算ケースで最も相関の高かった case01について , 河床位の遷移を約10年ごとにみた ものである.1980年代までは，河口域全般にわたっ て高い再現性が得られている.これは河床兴のもの

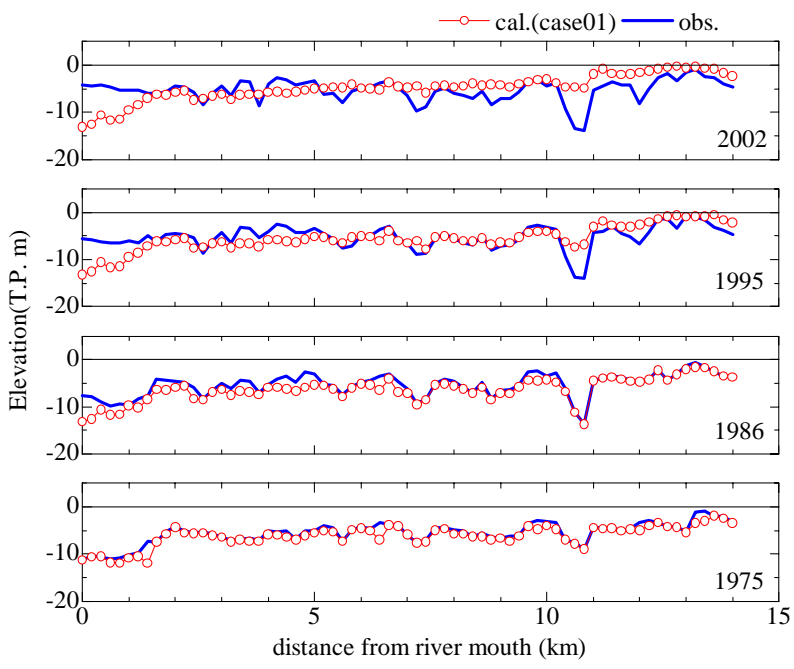

图- 3 河床変動計算結果と実測值との比較 (CASE01)

か計算当初と比べ大きく変化していないということ と，計算における砂利採取の扱いが最深河床位の浅 いところから多く採取するように仮定したため，こ の計算処理が結果的には計算結果と実測データの誤 差を埋め合わせる方向に働いている可能性が考えら れる、砂利採取については，量的な情報を把握でき ているものの，採取場所等の空間情報が欠落してい るために，これの取り扱いには注意が必要である。

また, 1995年以降では, 計算值の方が実測值より も10-15km区間で堆積，0-2kn区間で侵食する傾向が 強く出ており，掃流砂量がやや過小に評価されてい 

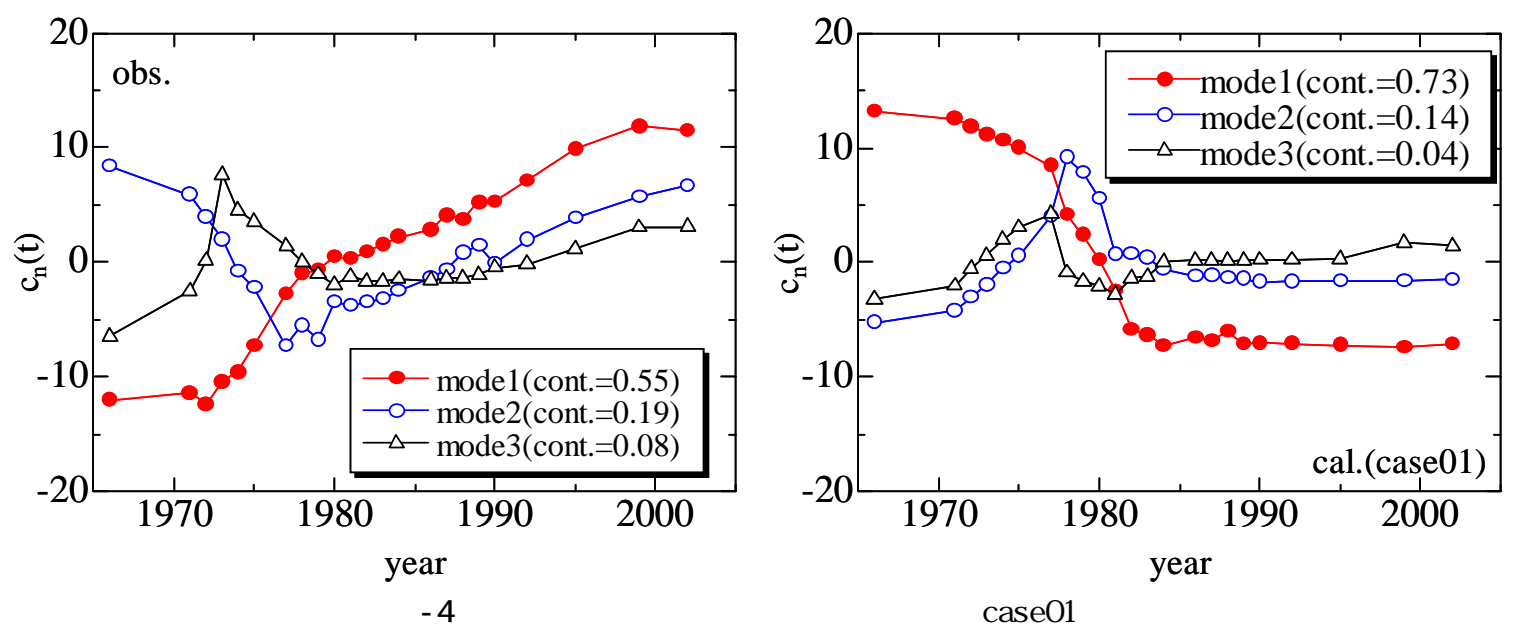

る可能性も考えられる. 特に本モデルでは岸沖方向 の沿岸漂砂を考慮していないために，0-2km区間の 沖側からの土砂供給に起因すると考えられる河床上 昇が再現できていない .

以上のことから本モデルでは岸沖方向の漂砂や局 所洗掘を再現できていないことに注意する必要があ るものの，2-10km区間ではある程度の再現性を得る ことができた .

\section{3. 経験的固有関数法を用いた河床変動要因の 抽出}

\section{（1）経験的固有関数法の概要}

加藤・吉松1)，中野・岡部2) は，実測データを対 象に経験的固有関数法を用いた地形变動の要因分析 を実施し，弚の有用性を確認している。

経験的固有関数法には変動現象の進行波成分と光 の位相関係を把握するための複素値解析と定常波を 対象とする実数值解析の2種類があるが, ここでは 従来から良く用いられる実数值型の2次元経験的固 有関数法を適用した。

いま，ある測量年 $t$ の河床位 (本研究では, 定期 横断測量データの各断面の最深河床位とする) $z_{b}(x, t)$ とする. 全測量期間平均の河床位を $\overline{z_{b}}$ と すると, 平均河床位からの変動量は

$$
z_{b}^{*}(x, t)=z_{b}(x, t)-\overline{z_{b}}(x)
$$

で表される.ここで， $t$ は測量年， $x$ は測量期間を 通じて同一位置を示す一種の格子番号に相当する . これを時間方向の固有関数 $c_{i}(t)$ と空間方向の固有 関数 $e_{i}(x)$ を用いて

$$
z_{b}^{*}(x, t)=\sum_{i=1}^{n} c_{i}(t) e_{i}(x)
$$

と表現する .ここで $e_{i}(x)$ は対象とする地形固有の ものであり，データから経験的に得られるものであ る . $c_{i}(t)$ と $e_{i}(x)$ は寄与率の大きい順に第1次モ一 ド $c_{1}, e_{1}$, 第2次モード $c_{2}, e_{2}$ 吅と呼ぶことにする なお，解析方法の詳細は加藤・吉松(1) の論文を参照

されたい .

（2）経験的固有関数法による河床変動要因の検討 河口付近の河床変動の特徵を抽出するため, 国土 交通省の定期横断測量データ及び前節の計算結果に 対し, 経験的固有関数法を用いた主成分分析を行っ た．解析対象区間は0-14km飞゙ある．前節の河床変動 計算では初期河床位は各断面の最深河床位としたた め, 実測データの解析においても，各断面の最深河 床位を用いることとした 。

図-4は寄与率の大きい順に3つの主成分の時間固 有関数を示したものである. 1966〜2002年の河床変 動量は，第3主成分までを考慮することにより実測 值に対し $82 \%$ 程度，計算值に対し $90 \%$ 程度以上が表 現できている .

時間関数の第1主成分を比較すると，実測値と計 算値で逆の傾向が見られ，実測值に対する第1主成 分は単調な上昇を示すのに対し，計算值に対する第 1主成分は単調な下降を示していた。

ところで, 河床変動量 $z_{b}^{*}$ は $c_{i}$ と $e_{i}$ の積で表さ れるため, $e_{i}>0$ の地点では $d c_{i} / d t>0$ の場合に 河床上昇傾向， $d c_{i} / d t<0$ の場合に河床低下傾向 となることを示す.一方 $d c_{i} / d t<0$ ではこれと逆 の関係がある .このため， $c_{i}$ の傾きが大きいとこ ろで地形の急激な上昇または下降が生じることを表 現できる .

例えば，図-5に示す空間関数において，11km地点 付近に着目すると，実測值に対する第1主成分は負 值であるのに対し，計算值に対する第1主成分は正 值をなっている．これにより，この地点の河床変動 の傾向は以下のように侵食傾向と判断される.

実測値

$$
<d c / d t><e>
$$

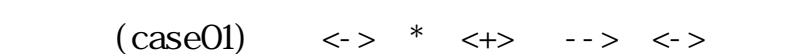

空間関数の第1主成分についてみると，全区間 

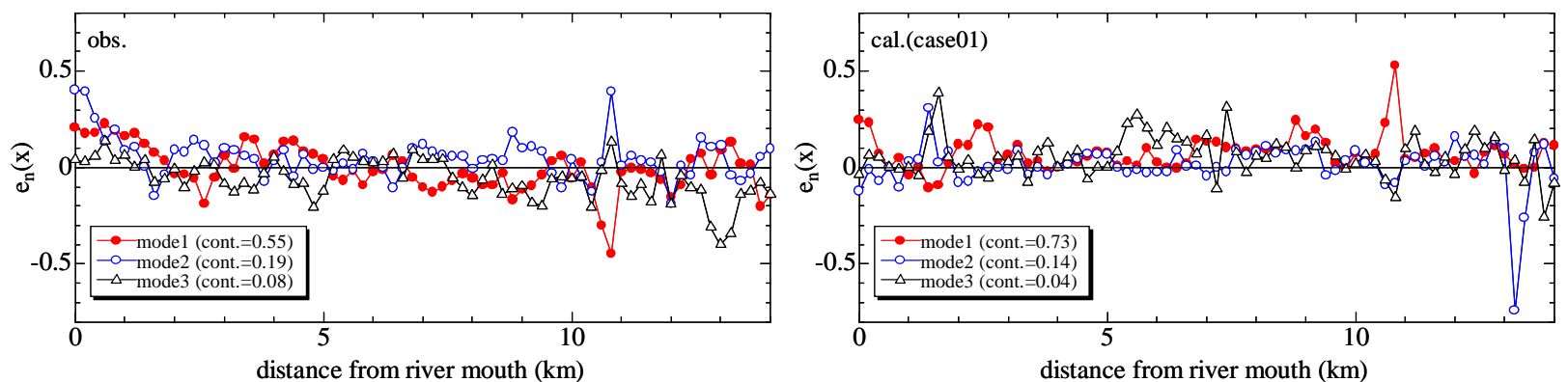

図- 5 空間関数の比較 (実測値, 計算値 (case01) )
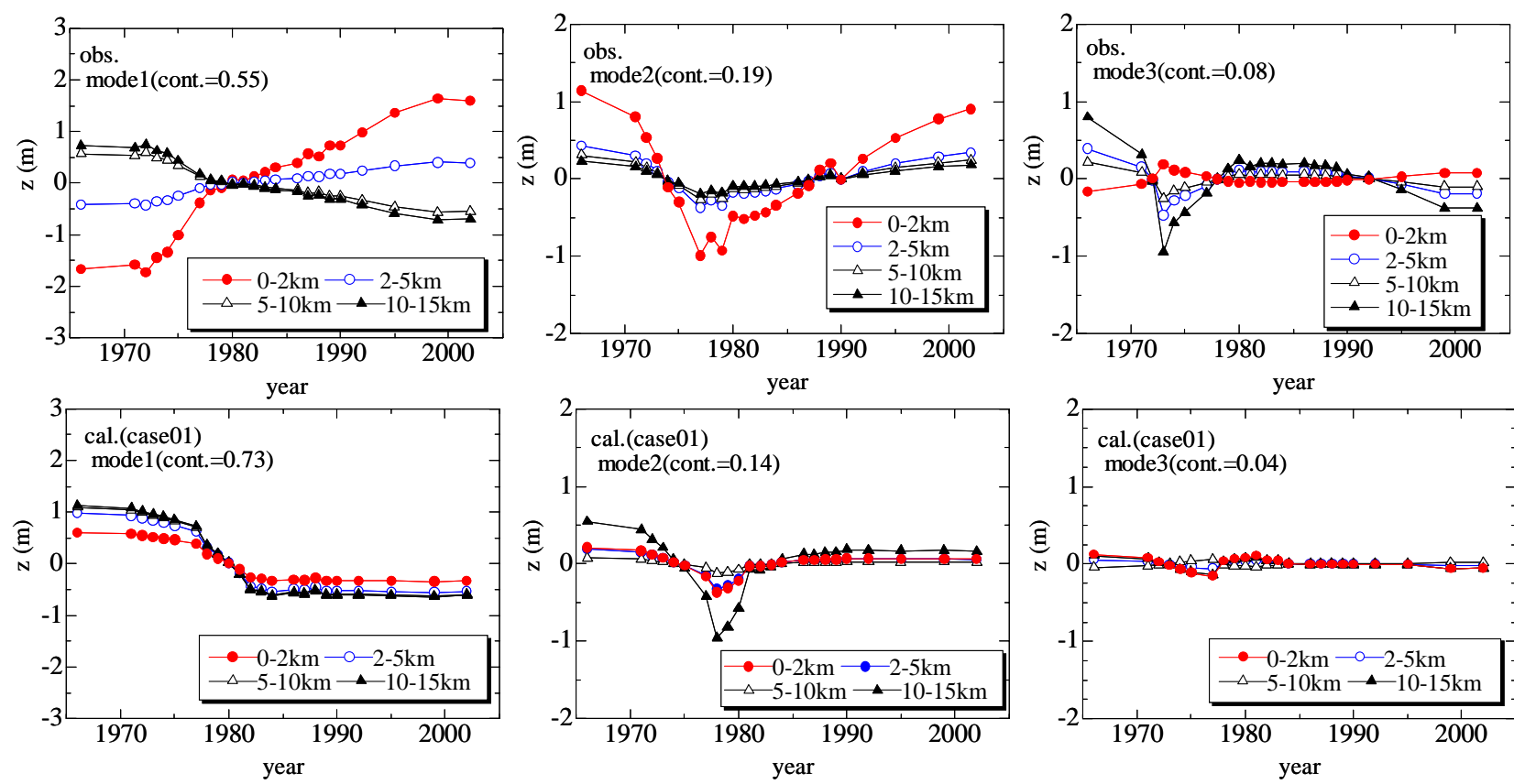

図-6 各主成分による平均最深河床位の変動（実測值, 計算值 (case01) )

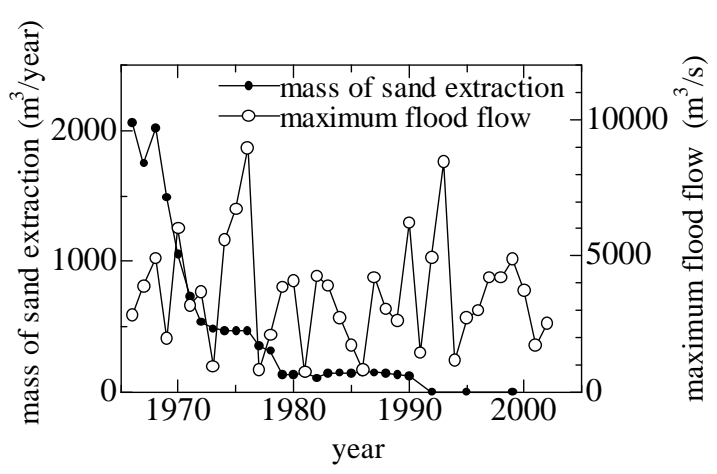

図- 7 砂利採取量と最大洪水日流量の経時变化

(0-14km) の多くの地点で害測值と計算值の空間関 数の符号が逆転している.このため, 時間関数の傾 きが実測值と計算値で反対であっても，河床変動の 傾向としてはよく似た傾向を示す．したがって，時

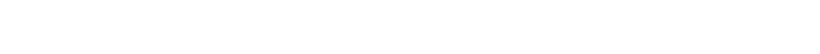
とも重要であるが, 時間関数と空間関数の組み合わ せで河床変動の傾向を評価する必要がある. 数値計 算では河口部の土砂堆積状況や局所洗掘の再現が低 かったため, 時間関数, 空間関数が実測値のものと
違う結果をもたらしたものと考えられる．

図-6は，式(9)を用いて各主成分に起因する河床 変動量を抽出したものである．寄与率の大きい第1 主成分による河床変動量についてみると, 実測值に 対する解析結果では，河口5kmまでの区間と光れよ り上流区間で河床変動の傾向が異なることがわかる． 1980年を境に, 弚れ以前は河口5kmより上流側で堆 積，下流側て侵食傾向にあったのが，1980年前後を 境に上流側で侵食，下流側で堆積傾向に転じている． 特に河口0-2km区間の最深河床部における堆積速度 は0. $1 \mathrm{~m} /$ 年程度となっている. 河口0-2kn区間で見ら れる河床上昇の傾向は海側から土砂供給を反映した ものと考えられる . また, 吉野川上流では，1973年 に早明浦ダム，1975年に池田ダムか竣工しており， これらのダム建設による土砂供給能の低下が，1980 年以降に河口 $5 \mathrm{~km}$ り上流側でみられる侵食傾向の 一因になっているとも考えられるが，これについて は, 解析対象区間を文么直下まで拡げてより詳細に 検討する必要がある。

一方，数値計算に対する解析結果では，1985年ま で0-14km全域でゆるやかな侵食傾向にあり，光れ以 


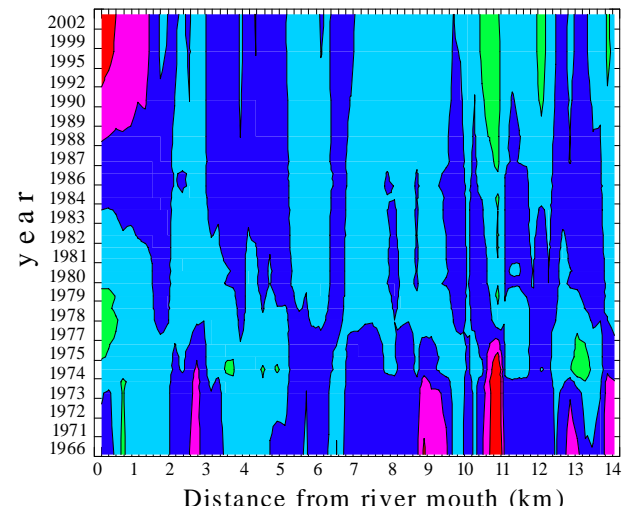

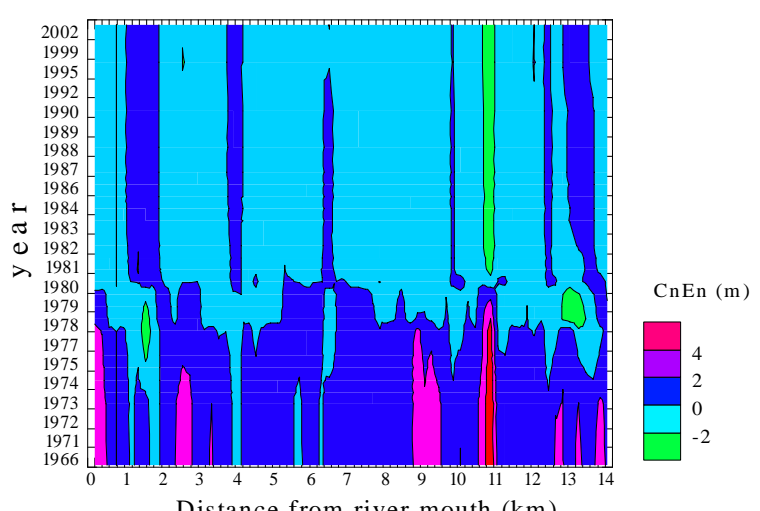

Distance from river mouth $(\mathrm{km})$

図-8 各主成分による平均最深河床位の変動（実測值，計算値（case01）)

降は変動がほとんど見られなかった . 特に0-2km区 間では実測値の変動量と大きく異なっていた .この 理由としては, 計算では岸沖方向からの土砂供給を 反映できなかったことが考えられる．

次に，第2主成分による河床変動についてみると， 実測値，計算值とも似た傾向を示しており，1980年 頃までは河床が低下し，1980年を境に河床はゆるや かな上昇傾向 (堆積速度 : $0.2 \mathrm{~m} /$ 年程度) にあるこ とがわかる．この傾向は，図-7に示す砂利採取量の 経年変化とよく似ており，砂利採取が活発に行われ た1975年頃までは河床は侵食されるが, 砂利採取事 業が急速に衰退する1980年代以降，河床は平衡状態 に向かっている . 経験的固有関数法で得られるモー ド関数の意味付けについては, 解析者の主観に頼ら ざるを得ない部分があり，ここでは単に両者の変化 傾向が似ているというだけであるが, 他にこのよう な経年変化を示すインパクトが見当たらないことと， 吉野川河口での砂利採取事業の規模から考えても， 砂利採取事業の動向が第2主成分による河床変動を 説明していると判断した .

第3主成分による河床変動量は, 実測値, 計算値 ともに似たような傾向を示したが, 第1, 第2主成分 に比へて炎の寄与率は大変小さいものとなっていた このことから，河口部の河床変動は概ね第1主成分 と第2主成分の因子によって説明されることがわか る.したがって, 数值解析では, 河口における岸沖 方向からの土砂移動量を正確に評価することや, 計 算対象域を超えた流域全体での人為的インパクト (ダム建設や流域産業の変遷 ) について考慮するこ とが重要である .

（3）経験的固有関数法による解析結果を用いた河床 変動量の再現性

経験的固有関数法を実施することにより，時間関 数 $c_{i}(t)$ と空間関数 $e_{i}(x)$ を用いて, 河床位変化を再 現することができる.図-8は，第3主成分までの時 間関数と空間関数を用いて, 河床変動量の時空間変 化を求めたものである .コンター色が赤いほど堆積 傾向，逆に青いほど侵食傾向にあることを示す．実 測値と解析值ともによく似た傾向を示しており，河
口における河床変動量の時空間分布を再現すること ができた .

\section{4. 結論}

本研究で得られた成果は以下のとおりである .

（1）本研究で用いたー一次元河床変動計算モデルでは， 河口0-2km区間の沖からの土砂供給, 局所洗掘 の再現に課題を残すが, 吉野川河口域の土砂移 動形態をある程度説明することができた．

（2）経験的固有関数法を測量データ並びに数値計算 結果に適用した結果, 吉野川の過去30年の地形 変動の要因として, 砂利採取や上流でのダム建 設といった人為的インパクトや岸沖漂砂河床変 動に影響を及ぼしている可能性が示唆された 。

(3) 経験的固有関数法で得られたモード3までの時 間関数, 空間関数を用いて河床変動量を概ね再 現することができた .

謝辞: 本研究は, 文部科学省科学研究費補助金 (基 盤研究(B) 17360236 , 研究代表者: 中野晋) の助成 を受けて行われた . また，横断測量等のデータにつ いては国土交通省四国地方整備局德島河川国道事務 所からこ提供頂いた .ここに記して謝意を表する。

\section{参考文献}

1) 加藤一正，吉松晃 : 三次元の経験的固有関数法による 深浅図解析方法, 港湾技術研究所報告, 第23巻, 第2号, pp. 27- 47, 1984.

2) 中野晋, 岡部健士 : 吉野川下流域の長期地形変動, 河 川技術論文集，Vol.8，pp. 207-212，2002.

3) 中野晋, 田所 真路, 宇野 宏司, 藤本 雅彦: 日本沿 岸の潮位に見られる長周期変動と温暖化の影響, 海岸 工学論文集, Vol.49, pp. 1351-1355, 2002.

4) 須賀克三 , 葛西敏彦 : 河川における不定流の計算不法 - 陰形式差分法 - , 土木研究所資料, 113p. , 1980.

5) 土木学会水理委員会 : 水理公式集例題プログラム集 [ 平 成13年版]，2002.

6) 黑木幹男, 岸力, 清水康行 : 河床変動の数值計算法に 関する研究, 第17回自然災害シンポジウム講演論文集, pp. $175-179,1980$.

(2006. 9. 30受付) 